УДК 81'373.7-115: 159.93

DOI https://doi.org/10.26661/2414-9594-2021-1-28

\title{
СЕМАНТИЧНІ ОСОБЛИВОСТІ ФРАЗЕОЛОГІЗМІВ НА ПОЗНАЧЕННЯ ЗМШАНИХ ВІДЧУТТІВ ЛЮДИНИ: ЗІСТАВНИЙ АСПЕКТ
}

\author{
Шульженко А. С. \\ кандидат філологічних наук, \\ старший викладач кафедри соціальних комунікацій \\ Бердянський державний педагогічний університет \\ вул. Шмідта, 4, Бердянськ, Запорізька область, Україна \\ orcid.org/0000-0003-4767-8049 \\ denisova1108@gmail.com \\ Ліпич В. М. \\ кандидат філологічних наук, \\ доиент кафедри української мови та славістики \\ Бердянський держсавний педагогічний університет \\ вул. Шмідта, 4, Бердянськ, Запорізька область, Украӥна \\ orcid.org/0000-0002-1892-1102 \\ lipich2508@gmail.com
}

\begin{abstract}
Ключові слова: фразеологічна одиниия, змімані відчуття людини, метафора, ізоморфні та аломорфні властивості.
\end{abstract}

У статті розглядаються семантичні особливості фразеологізмів на позначення змішаних відчуттів в українській, англійській та французькій мовах, які описують не пізнання людиною навколишнього світу за допомогою органів чуття, а виявлення факторів і загроз, які можуть завдати як користі, так і шкоди іiі організму. Емпіричний матеріал дає змогу стверджувати, що такі стійкі сполуки займають вагоме місце у фразеологічних корпусах досліджуваних мов.

Фразеологізми на позначення змішаних відчуттів людини - це мовні одиниці із семантикою холоду/тепла, болю та вібрації. Найчисельнішими $\epsilon$ стійкі сполуки на позначення відчуття холоду, які характеризуються метафоричними перенесеннями «предмет, який впливає на організм людини і викликає дискомфорт від низької температури навколишнього середовища $\rightarrow$ людина, яка відчуває холод»; «тварина, риба, яка зазнає впливу зниженої температури повітря $\rightarrow$ людина, яка відчуває холод». Окрім цього, на основі метонімічного перенесення, а саме синекдохи, «орган, який зазнає впливу низької температури $\rightarrow$ людина, яка відчуває холод» утворена значна кількість ФО із семантикою холоду.

В опозиційні відношення до фразеологізмів на позначення відчуття холоду вступають одиниці зі значенням тепла. Зіставний аналіз дає змогу стверджувати, що в основу таких мовних сполук покладені лексеми, номінативне значення яких характеризується підвищенням температури навколишнього середовища або тіла людини. Фразеологізми на позначення больових відчуттів мають свою специфіку. Це зумовлено тим, що біль може бути в усьому тілі або лише в окремих органах. Актуалізаторами в таких ФО найчастіше виступають соматизми. Найменш вживаними є стійкі сполуки на позначення вібраційних відчуттів, семантика яких пов’язана 3 тремтінням, дрижанням частин людського тіла від холоду або страху.

У результаті порівняльного аналізу фразеологізмів вдалося виявити їхні спільні та відмінні властивості. Образну основу таких одиниць становлять порівняння із тваринами на основі метафоричного та метонімічного перенесення. 


\title{
SEMANTIC PECULIARITIES OF PHRASEOLOGICAL UNITS DENOTING MIXED HUMAN FEELINGS: COMPARATIVE ASPECT
}

\author{
Shulzhenko A. S. \\ Candidate of Philological Sciences, \\ Senior Lecturer at the Department of Social Communications \\ Berdyansk State Pedagogical University \\ Schmidt str., 4, Berdyansk, Zaporizhia region, Ukraine \\ orcid.org/0000-0003-4767-8049 \\ denisova1108@gmail.com \\ Lipych V. M. \\ Candidate of Philological Sciences, \\ Associate Professor at the Department of Ukrainian Language and Slavic Studies \\ Berdyansk State Pedagogical University \\ Schmidt str., 4, Berdyansk, Zaporizhia region, Ukraine \\ orcid.org/0000-0002-1892-1102 \\ lipich2508@gmail.com
}

Key words: phraseological units, mixed human feelings, metaphor, isomorphic and allomorphic properties.
In the article semantic peculiarities of phraseological units denoting mixed human feelings in Ukrainian, English and French, which are characterized not by knowledge of the world through the senses, but by identifying factors, threats that can benefit both the school and the human body. The empirical material gives opportunity to assert that they are very important in phraseological corpus of studied languages.

The units with semantics of cold / heat, pain, vibration are included to phraseological units denoting mixed feelings. The most numerous are stable compounds denoting of cold, which are characterized by isomorphic metaphorical transfers "part of the body, subject, which effects the human body and causes discomfort from low temperature of the world - person who feels cold"; "an animal, fish which feels the effect of low temperature - a person who feels cold". In addition, on the basis of metonymic transference, synecdoche, "an organ effected by low temperature - a person who feels cold" a significant number of phraseological units with semantic of cold are created. In opposition relations to phraseological units denoting human feelings of cold enter units denoting of heat. The comparative analysis gives opportunity to assert that feeling of increasing the temperature of the world or the human body is connected with lexemes, nominative meaning of which is inextricably connected with this phenomenon. The phraseological units denoting pain have their own specific. This is due to the fact that the pain can take place in the whole body or in some organs. Actualizers in such phraseological units are often somatisms. The least commonly used are stable compounds denoting vibration feelings, semantics of which are connected with trembling, trembling of parts of the human body from cold or fear.

As a result of comparative study of giving phraseological units it was possible to identify their isomorphic and allomorphic properties. The figurative basis of such units is comparisons with animals on the basis of metaphorical and metonymic transference. 
Постановка проблеми. Інтенсивний розвиток фразеології характеризується широким колом проблем, які досліджуються на матеріалі слов'янських, германських та романських мов. Порівняльний аналіз семантики ФО (далі - фразеологізмів) неблизькоспоріднених мов дає змогу вирішити важливе питання сучасних зіставних досліджень - розкрити взаємозв'язок мови, культури та свідомості певного етносу.

Фразеологізми антропоцентричної спрямованості, тобто орієнтованості на людину, неодноразово були в центрі уваги як вітчизняних, так i зарубіжних лінгвістів (М.Ф. Алефіренко [1], I.В. Гарбера [2], Н.Ф. Грозян [3], О.В. Забуранна [4], О.М. Каракуця [5], Ж.В. Краснобаєва-Чорна [6], К.І. Мізін [7], Ю.Ф. Прадід [8], О.О. Селіванова [9], В.М. Телія [10], А.С. Шульженко [11] та ін.). Дослідження фразеології на основі принципу «людини в мові» призвело до іiі бурхливого розвитку, що дало змогу зробити акцент на психологічних аспектах формування фразеологічної картини світу, а культурні феномени розглядати як константи культури. Отже, антропоцентризм характеризується зміщенням акцента 3 об'єкта пізнання на його суб’єкт, тобто аналізує людину в мові і мову в людині.

Мета статті полягає в зіставному аналізі фразеологізмів на позначення змішаних відчуттів людини та визначенні їхнього місця у фразеологічній картині світу носіїв досліджуваних мов.

Виклад основного матеріалу. ФО на позначення змішаних відчуттів людини - це мовні одиниці, які описують стан, за якого організм піддається впливу як зовнішніх, так і внутрішніх подразників. Сюди належать фразеологізми на позначення температурних (холоду та тепла), вібраційних та больових відчуттів людини [11]. Емпіричний матеріал засвідчує вагоме місце аналізованих одиниць у фразеологічних корпусах української, англійської і французької мов.

Стійкі сполуки із семантикою температурних відчуттів є найбільш вживаними. Такий різновид відчуттів людини сигналізує про зміни температурного середовища, про небезпеку охолодження організму чи його перегрівання, допомагає регулювати тепловий обмін між організмом і середовищем i поділяється на два типи: відчуття холоду й тепла.

На позначення відчуття холоду нами виявлено значний масив фразеологічних одиниць в усіх досліджуваних мовах. Оскільки фразеологізми із семою «мерзнути» означають дискомфорт, приховану/явну небезпеку для життя людини, то актуальним є метафоричне переосмислення ФО: «Предмет, який впливає на організм людини і викликає дискомфорт від низької температури навколишнього середовища $\rightarrow$ людина, яка відчуває холод». В українській мові це такі одиниці: мороз бере з-за плечей, мороз по шкірі подирає, змерзти на качан. Як бачимо, актуалізатором у таких сполуках є іменник «мороз» - холод, коли температура повітря спадає нижче нуля, та дієслово «змерзнути», тобто відчувати холод, страждати від холоду; мерзнути [12, Т. 3, с. 615]. Із наведеного зрозуміло, що складники фразеологічної одиниці вживаються у своєму номінативному значенні, де на лексичному рівні означають холод. Таку ж тенденцію до утворення мають і ФО англійської мови. Компонентами стійких сполук на позначення низької температури навколишнього середовища виступають лексеми озноб, охолодження, лід, холод (send chills down/up sb's spine, be chilled to the marrow (bones), be on ice, be dead with cold). ФО французької мови мають схожу тенденцію до утворення, обов'язковими складниками в них є лексеми із семантикою холоду (лід, холод): tourner au glaçon, le froid gratte le dos, claquer de froid.

Вагому частину у складі фразеологізмів на позначення відчуття холоду становлять переосмислені образи зоосемізмів. Метафоричне перенесення «тварина, риба, яка зазнає впливу зниженої температури повітря $\rightarrow$ людина, яка відчуває холод» асоціюється носіями української мови 3 такими тваринами, як собака (змерз, як собака, хоч псів гони, собачий холод); вовк (хоч вовків ганяй); тур (Так замерзло, що хоч тури гони); в англійській мові - з мавпою (brass monkey weathe); борсуком (as) blue as a badger); а також іхтіонімом риба (as) cold as a fish); у французькій мові - $з$ вовком (froid de loup, faire froid de loup); собакою (faire froid de chien); качкою (il fait un froid de canard); куркою (avoir la chair de poule). Окрім цього, компонентом ФО є іхтіонім риба (froid comme un poisson). У трьох мовах спостерігається тенденція до асоціації відчуття холоду 3 однаковими представниками тваринного світу: в українській та французькій мовах - це собака, вовк, курка; в англійській та французькій - риба.

Соматизми - невід'ємний компонент в утворенні ФО на позначення відчуттів людини, не $є$ винятком і відчуття холоду. На основі метонімічного перенесення, а саме синекдохи, «орган, який зазнає впливу низької температури $\rightarrow$ людина, яка відчуває холод» утворені ізоморфні ФО з компонентом зуби (укр. иэокотіти (цокотати, цокати, ляскати) зубами, аж кувати вухналі зубами, вибивати зубами чечітку (третяка), ляскати зубами; англ. smb's teeth chatter [from cold (frigth)]; $\phi \mathrm{p}$. claquer des dents, se taper sur la lanterne); кістки (укр. пронизувати до [самих] кісток, мороз пробирається до [самих] кісток; англ. be chilled to the bone (to the marrow of one's bones). Окрім цього, в англійській мові зафіксовані ФО з такими соматизмами, як мозок (be frozen to the marrow), ноги (cold feet, get cold feet); у французькій - шкіра (avoir la 
chair de poule), сідниці (se geler le cul, se geler les couilles), які характеризуються аломорфністю.

Специфічним явищем для української мови $\epsilon$ роль метафори в утворенні ФО на позначення стану поколювання в кінцівках від холоду: зашпори заходять / зайшли «Оие зашпари зайшли, де «шпари» - це гострий біль від морозу, холоду [12, T. 3, c. 417].

В опозиційні відношення до проаналізованих вище ФО вступають стійкі сполуки із значенням відчуття тепла. Зазначена група фразеологізмів характеризується наявністю у своєму складі інтегральних сем «спека», «жар».

Коли в навколишньому середовищі спекотно, дуже нагріте сонячними променями повітря, в людини виникає дискомфорт. Для опису стану людського тіла в таких умовах в українській мові функціонують фразеологізми залитися (заллятися) потом), як (мов, ніби) скупали в окропі, гаряче, як у лазні (як у кузні). Актуалізаторами в наведених ФО є лексеми nim, окріп, лазня, кузня, номінативне значення яких співвідноситься 3 високою температурою. В англійській мові ключовими лексемами в таких ФО виступають піч, вогонь, полум'я, вугілля, пекло, що мають семантику речовин або місця, де спостерігається дуже висока температура повітря (as) hot as a furnace (as fire, as flame), (as) hot as coals. У французькій мові зі значенням спеки вживається ФО cuire dans son jus (baigner dans son jus).

Із семантикою «жар», або підвищена температура тіла при захворюванні $[12$, Т. 11, с. 508], в українській мові функціонують фразеологізми, утворені шляхом метафоричного перенесення «вплив джерела високої температури на організм людини $\rightarrow$ людина, яка відчуває жар». Актуалізаторами є іменники вогонь, полум'я, жар, пряме значення яких повністю відповідає семантиці ФО (вогнем (полум'ям) горіти, обсипає (осипає) / обсипало (осипало) жаром [гарячим] приском), палити вогнем). Схожу модель утворення мають як англійські фразеологізми, основними компонентами яких є лексеми сяйво, nim, вогонь, niy (be of a glow, bring out the sweat on one's body, to, burn like fire), так і французькі (brûler comme un charbon, son corps est un brasier). Отже, у свідомості людей незалежно від їхньої національної належності відчуття підвищення температури навколишнього середовища або тіла людини пов'язане 3 лексемами, номінативне значення яких нерозривно пов'язане з цим явищем (вогонь, полум'я, піч, вугілля, пекло тощо).

На відміну від інших різновидів відчуттів людини, за допомогою яких вона отримує інформацію про навколишній світ, біль надає мало відомостей про нього. Його функція - повідомляти про внутрішні та зовнішні небезпеки, які загро- жують людському організму. Біль - це неприємне сенсорне та емоційне переживання, пов'язане 3 істинним або потенційним пошкодженням тканин [12, Т. 1, с. 248-252].

Фразеологізми на позначення больових відчуттів мають свою специфіку. Біль може бути в усьому тілі або локалізуватися лише в окремих органах. Для опису головного болю найчастіше використовуються ФО з однойменним компонентом-соматизмом, як-от: укр. як (мов, ніби) сови ночували в голові; фp. mal de tête. Аналізовані ФО утворюються на основі метонімії «орган, який викликає неприємні (больові) відчуття в людини $\rightarrow$ людина, яка відчуває головний (зубний) біль» (укр. голова розвалюється (розривається, розлітається, тріщить; англ. splitting headache; фp. avoir la tête (fendue) en quatre або mal de dents], craquer des dents).

На основі метафори «дія на організм людини, яка викликає біль $\rightarrow$ людина, яка відчуває біль у різних частинах організму» утворені сполуки із семантикою болю між ребрами (укр. ссати (смоктати) під ложечкою), у боку (англ. give (one) a stitch, to), в очах (фp. tomber sur le coin de l'œil).

На позначення болю в усьому тілі в українській мові функціонують фразеологізми як (ніби, наче) поламаний, вивело очі на лоб (на лоба) дух запирає, що сигналізують про погіршення загального стану організму, відчуття слабкості і млявості. У французькій мові для опису цього відчуття використовується ФО avoir mal, де компоненти виконують номінативну функцію.

Наслідком реакції на біль $є$ спазм, тобто стійке мимовільне скорочення м'язів або окремих їх волокон (стравоходу, кишечника, шлунка, горла) $[12$, T. 1, c. 483]. Для його позначення у свідомості людей сформувалися асоціативні уявлення 3 частинами тіла, які безпосередньо беруть участь у цьому процесі. В українській та французькій мовах вживається метафора «дія на організм людини, яка викликає спазм $\rightarrow$ людина, яка відчуває спазм» клубком підступати (niдступити, підкочуватися, підкотитися) до горла); фр. avoir ипе barre, tordre les boyaux. Аломорфним є вживання фразеологізмів у французькій мові, які характеризують біль людини під час хвороби (pisser des lames de rasoir, pisser entre parentheses).

Вібраційні відчуття нерозривно пов'язані зі слуховими. Вібрація - це механічне коливання якого-небудь тіла, що відбувається 3 великою частотністю та невеликою амплітудою дрижання $[12$, T. 1, c. 549$]$.

Фразеологізми, семантика яких пов'язана 3 тремтінням, дрижанням частин людського тіла, утворені на основі метафоричного перенесення «частина дерева, речовина, яка тремтить від впливу вітру $\rightarrow$ людина, яка дрижить, тремтить». Такі ФО репрезентовані компаративними стійкими 
сполуками, які функційно спрямовані на пізнання об'єктивного світу за допомогою зіставлення предметів/явищ/процесів та $\epsilon$ внутрішньо-організованою системою поняттєвих, емоційних, фоносемантичних структур, взаємодія яких сприяє творенню фразеологічної картини світу [13, с. 91]. В українській мові це фразеологізм дрижати як осиковий лист, в англійській - tremble like a leaf, quiver like a jelly, у французькій - trembler comme la feuille. Проаналізовані ФО із семою «тремтіти» мають різні передумови виникнення цього стану: переляк, страх, переживання, зміна температури навколишнього середовища.

Схожу семантику, але іншу структуру мають ФО зі значенням «тремтіти від холоду». Метафора «частина тіла, яка зазнає тремтіння від холоду $\rightarrow$ людина, яка тремтить від низької температури навколишнього середовища» репрезентована в таких одиницях: укр. вибивати (бити) дрижаки (дроб), [аж] мороз іде (подирає, пробирає) / подер (подрав, пробрав) по шкурі; фр. frissonner de froid, avoir la tremblote, le petite mort. Спільною ознакою для зіставлюваних фразеологізмів є компонент, який передає процес вібрації. В англійській мові не виявлено ФО на позначення тремтіння від холоду.

Висновки. Отже, семантика фразеологізмів на позначення змішаних відчуттів людини описує не пізнання людиною навколишнього світу за допомогою органів чуття, а виявлення факторів, загроз, які можуть завдати як користі, так і школи їі організму. Образну основу аналізованих ФО часто формують порівняння із тваринами на основі метафоричного та метонімічного перенесення. Домінуванням та ізоморфністю характеризуються ФО із семантикою температурних відчуттів, зокрема холоду, найменшою вживаністю зі значенням вібраційних відчуттів.

Перспективи подалыших пошуків вбачасмо в розширенні жанрово-стильових рамок емпіричного матеріалу й залученні до аналізу художніх, публіцистичних та інтернет-текстів з метою встановлення частотності функціонування стійких сполук у контексті, а також для виявлення їхніх структурно-семантичних трансформацій.

\section{ЛІТЕРАТУРА}

1. Алефиренко Н.Ф. Спорные проблемы семантики : монография. Москва : Гнозис, 2005. 326 с.

2. Гарбера І.В. Концепт людина у фразеології східностепових українських говірок : автореф. дис. ... канд. філол. наук : 10.02.01. Вінниця, 2018. $22 \mathrm{c.}$

3. Грозян Н.Ф. Фразеологічна мікросистема «Поведінка людини» в українській мові (ідеографічний $\mathrm{i}$ аксіологічний аспекти) : автореф. дис. ... канд. філол. наук : 10.02.01. Дніпропетровськ, 2003. 20 с.

4. Забуранна О.В. Антропоцентризм фразеологічної семантики (на матеріалі фразеологічних одиниць української, перської, японської мов зі значенням відносного часу) : автореф. дис. ... канд. філол. наук : 10.02.15. Київ, 2003. 18 с.

5. Каракуця О.М. Фразеологізми української мови з компонентом «душа» (структурно-семантичний, ідеографічний, лінгвокультурологічний аспекти) : автореф. дис. ... канд. філол. наук : 10.02.01. Харків, 2002. 19 с.

6. Краснобаєва-Чорна Ж. Фраземіка та фраземографія в сучасній лінгвопарадигмі : підручник для студентів філологічних факультетів вищих навчальних закладів / за ред. А.П. Загнітка. Вінниця : Нілан, 2018. 200 с.

7. Мізін К.І. Порівняння у фразеології. Вінниця : Нова Книга, 2009. 240 с.

8. Прадід Ю.Ф. Фразеологічна ідеографія (проблематика досліджень). Київ ; Сімферополь, 1997. 252 с.

9. Селіванова О.О. Нариси з української фразеології (психокогнітивний та етнокультурний аспекти) : монографія. Київ - Черкаси : Брама, 2004. 276 с.

10. Телия В.Н. Русская фразеология. Семантический, прагматический и лингвокультурологический аспекты. Москва : Школа «Языки русской культуры», 1996. 286 с.

11. Шульженко А.С. Фразеологізми на позначення відчуттів людини в українській, англійській і французькій мовах: структурний та семантичний аспекти : автореф. дис. ... канд. філол. наук : 10.02.17. Вінниця, 2020. 20 с.

12. Словник української мови : в 11 т. [ред. колег. І. К. Білодід (голова) та ін.]. Київ : Наукова думка, 1970 - 1980. T. 3: 3. 1972.840 c. ; T. 11: X - b. 1980.699 c. ; T. 1: A-B. 1970.799 c.

13. Лисенко Л. Структурні типи порівняльних фразеологічних одиниць (на матеріалі англійської, німецької та української мов). Наукові записки Кіровоградського державного педагогічного університету імені Володимира Винниченка. Серія : Філологічні науки. Кіровоград, 2010. Вип. 89(3). С. 90-97.

\section{REFERENCES}

1. Alefirenko N. F. (2005) Spornye problemy semantiki : monografiya. [Controversial problems of semantics: monograph]. Moscow : Gnozis. (in Russian). 
2. Harbera I. V. (2018). Kontsept liudyna u frazeolohii skhidnostepovykh ukrainskykh hovirok [The concept human in the phraseology of eastern steppe Ukrainian dialects]: (PhD Thesis). Vinnytsia : Vasyl' Stus Donetsk National University.

3. Hrozian N. F. (2003). Frazeolohichna mikrosystema «Povedinka liudyny» v ukrainskii movi (ideohrafichnyi $i$ aksiolohichnyi aspekty) [Phraseological microsystem «Human behavior» in the Ukrainian language (ideographic and axiological aspects)] : (PhD Thesis). Dnipropetrovsk : Dnipropetrovsk National University.

4. Zaburanna O. V. (2003). Antropotsentryzm frazeolohichnoi semantyky (na materiali frazeolohichnykh odynyts ukrainskoi, perskoi, yaponskoi mov zi znachenniam vidnosnoho chasu) [Anthropocentrism of phraseological semantics (on the material of phraseological units of Ukrainian, Persian, Japanese languages with the meaning of relative time)] : (PhD Thesis). Kyiv : Taras Shevchenko National University of Kyiv.

5. Karakutsia O. M. (2002). Frazeolohizmy ukrainskoi movy z komponentom «dusha» (strukturnosemantychnyi, ideohrafichnyi, linhvokulturolohichnyi as-pekty) [Phraseologisms of the Ukrainian language with the component «soul» (structural-semantic, ideographic, linguo-cultural aspects)] : (PhD Thesis). Kharkiv : Kharkiv State Pedagogical University of G.S.Skovoroda.

6. Krasnobaieva-Chorna Zh. (2018). Frazemika ta frazemohrafia v suchasnii linhvoparadyhmi: pidruchnyk dlia studentiv filolohichnyk fakultetiv vyshchykh navchalnykh zakladiv [Phrasemics and phrasemography in the modern linguistic paradigm: a textbook for students of philological faculties of higher educational institutions]. Vinnytsia : Nilan. (in Ukrainian).

7. Mizin K. I. (2009). Porivniannia u frazeolohii [Comparison in phraseology]. Vinnytsia : Nova Knyha. (in Ukrainian).

8. Pradid Yu. F. (1997). Frazeolohichna ideohrafia (problematyka doslidzhen) [Phraseological ideography (research issues)]. Kyiv ; Simferopol. (in Ukrainian).

9. Selivanova O. O. (2004). Narysy z ukrainskoi frazeolohii (psykhokohnityvnyi ta etnokulturnyi aspekty) : monohrafiia [Essays on Ukrainian phraseology (psychocognitive and ethnocultural aspects): monograph]. Kyiv - Cherkasy : Brama. (in Ukrainian).

10. Teliya V. N. (1996). Russkaya frazeologiya. Semanticheskij, pragmaticheskij i lingvokul'turologicheskij aspekty [Russian phraseology. Semantic, pragmatic and linguocultural aspects]. Moscow : Shkola «Yazyki russkoj kul'tury». (in Russian).

11. Shulzhenko A. S. (2020) Frazeolohizmy na poznachennia vidchuttiv liudyny $v$ ukrainskii, anhliiskii $i$ frantsuzkii movakh: strukturnyi ta semantychnyi aspekty [Phraseological Units Denoting Human Feelings in Ukrainian, English, and French: Structural and Semantic Aspects]: (PhD Thesis). Vinnytsia : Vasyl' Stus Donetsk National University.

12. Bilodid I. K. (ed.) (1970-1980). Slovnyk ukrainskoi movy : v 11 t. [Dictionary of the Ukrainian language : in 11 vols]. Kyiv : Naukova dumka. T. 3: Z. 1972.840 s. ; T. 11: Kh - . 1980. 699 s.; T. 1 : A-V. 1970. 799 s. (in Ukrainian).

13. Lysenko L. (2010) Strukturni typy porivnialnykh frazeolohichnykh odynyts (na materiali anhliiskoi, nimetskoi ta ukrainskoi mov) [Structural types of comparative phraseological units (based on English, German and Ukrainian languages)]. Naukovi zapysky Kirovohradskoho derzhavnoho pedahohichnoho universytetu imeni Volodymyra Vynnychenka. Seriia : Filolohichni nauky [Scientific notes of Kirovohrad State Pedagogical University named after Volodymyr Vynnychenko. Series: Philological Sciences]. Vol. 89 (3). Kirovohrad, pp. 90-97. 